\title{
MEN FOR ALL SEASONS? \\ THE STRATHBOGIE EARLS OF ATHOLL AND THE WARS OF INDEPENDENCE, c.1290-c.1335.
}

\author{
ALASDAIR ROSS \\ Part 1: Earl John (1266X1270-1306) and Earl David III (c.1290-1326). ${ }^{1}$
}

When Edward Balliol died without direct heirs in 1364, the dynastic rivalry between the Bruce and Balliol families that had existed since 1290 came to an end. Although

- the Balliol family eventually lost the right to be recognised as 'kings of Scots', this does not mean that contemporaries, like the Strathbogie earls of Atholl, should not have supported them. Indeed, it is occasionally very difficult to decide exactly how people fell about this dynastic conflict in Scotland, mainly because the reign of Robert Bruce (1306-29) was accompanied by a massive propaganda campaign aimed at justifying his seizure of the throne. ${ }^{2}$ The effectiveness of this material is still evident after almost seven hundred years. Also, until recently, historiography has largely presented the wars of independence from a monarchocentric perspective and this type of approach can lead to categorisations regarding nationalism and loyalty. For example, the popular and powerful image of 'good king Robert' means, rightly or wrongly, that anyone who actively opposed the Bruce dynasty, like Earl David III de Strathbogic, must have been 'treacherous'. ${ }^{3}$ A recent article on the period after 1332, when Edward Balliol returned to Scotland, advocates this view: 'The immediate consequence of Halidon was to set up an English-backed "Quisling" regime under Balliol which ceded a substantial part of southern Scotland to Edward III. (Perhaps Vichy would be a closer parallel!). ${ }^{14}$ Quite apart from the fact that such terminology introduces a new and irrelevant set of biases into medieval historiography, judgmental statements of this kind also imply that the Bruce cause was the 'right' causc. Contemporaries may not have thought so. After all, Robert Bruce had already provided a powerful precedent for seizing the Scottish throne. Were the actions of Edward Baltiol and his supporters any different? Why should they be expected to support a regime founded by an excommunicated murderer? Furthermore, the 1330s were certainly not the first occasion when kings of Scotland had either ceded territory to kings of England or utilised English military support to further their own dynastic claims. ${ }^{5}$

Perhaps the biggest problem with this type of approach is that it fails to take into account a wide range of political and non-political factors which may have influenced the way different families responded to the polarisation of loyalties between Plantagenet, Balliol and Bruce in Scotland after 1306. Probably the most important of these considerations is established Anglo-Norman landholding patterns. At the beginning of the fourteenth century, many families had held lands in both Scotland and England for a considerable period and had well-established obligations and responsibilities in each realm. Moreover, they were accustomed to giving service 
to more than one king, in return for patronage, without interference. ${ }^{6}$ For much of the thirteenth century this had not been a problem. Relations between the two realms had been peaceful. Indeed, the terms of the marriage treaty of Birgham (1290), agreed by the Guardians and probi homines of Scotland, implicitly accepted that any son of princess Margaret and Edward of Caernarvon would rule both realms. However, with the advent of the wars of independence, families were increasingly pressured to give their loyalty to one particular king, to the exclusion of the other. Robert I, for example, was particularly adept at this even though this concept must have been very unfamiliar to many members of the Anglo-Norman baronage of the period. Therefore, rather than following a monarchocentric nationalist approach and categorising these Anglo-Norman families as either 'Scottish' or 'English' or, as 'loyal' or 'disloyal', it might be better to examine how some families attempted to preserve their properties and rights in both realms in the face of increasing hostility from three royal dynasties, Plantagenet, Balliol and Bruce. Of the two Strathbogie earls of Atholl under consideration in this first article, one, Earl John, largely chose to support Robert Bruce. In contrast, his successor, Earl David III, only entered Bruce's allegiance for very short periods of time and spent the majority of his adult life in England. Were these radically different political stances a product of abstract principles like 'national politics' or, instead, the result of different attempts to preserve their perceived rights in both Scotland and England?

\section{Earl John (1266X1270-1306)}

\section{Marriage, Kinship and the Anglo-Norman World}

The history of the Strathbogie family during the first half of the thirteenth century is an ill-documented and largely obscure topic. In the male line, the Strathbogie earls of Atholl were apparently descended from David de Strathbogie (see Appendix 1), a third son of the earl of Fife. This David had received the lordship of Strathbogic in the early thirteenth century. The connection between this David de Strathbogic and the first Strathbogie earl of Atholl, Earl David II, is not certain; Earl David II might have been either the son or grandson of the first David de Strathbogie. Also, it is still not clear why Earl David II was originally granted the earldom of Atholl. One suggestion might be that his mother was related to the previous incumbents of the earldom. ${ }^{7}$ It is, however, the identity of Earl David II's wife that is particularly interesting. She was an English heiress, Isabella de Dover (or Chilham), granddaughter of King John I of England through an illegitimate line. ${ }^{8}$ The marriage between Earl David II and Isabella de Dover may have been one product of the closer contacts between Scotland and England which resulted from the marriage, in 125I, of Alexander III and Margaret, daughter of King Henry III. ${ }^{9}$ However, there is no record of an earl of Atholl attending the Scottish court during the minority of Alexander 111 and the earldom may have been in wardship during this period. ${ }^{10}$ Consequently, it is perhaps more likely that Earl David II and Isabella de Dover met after 1258, during the period of English baronial revolt. A number of Anglo-Norman lords who held lands in Scotland were fighting in England at the time: John Balliol, father of King, 
John Balliol of Scotland, was appointed as a councillor to Prince Edward ${ }^{11}$ and, in 1264, Balliol commanded a contingent of Scottish knights and troops on the royalist side at the battle of Lewes. This contingent included John Comyn of Badenoch and Robert Bruce (the Competitor); ${ }^{12}$ Comyn was rewarded with both the lands of an enemy of Henry III, and money. ${ }^{13}$ It is possible that Earl David II also fought on the royalist side and thus won his royal bride, although his name does not appear in any of the primary records or historiography describing this period of baronial conflict in England. ${ }^{14}$ The only writer which mentions Earl David II during this period is Walter Bower, who informs us that David was knighted by Alexander III in December 1264 at Scone. ${ }^{15}$

Of course, the most important aspect of the marriage, at least as far as Earl David II was concerned, must have been the identity of the bride. This important act of patronage by Henry III gave Earl David II entry into the extended royal Plantagenet family and its Angevin empire. Their son, John de Strathbogie, future earl of Atholl, was a Plantagenet and a cousin of King Edward I of England. There is no record of what Earl David II did to earn this royal favour, but if it was given for supporting Henry III against his barons, the rewards handed out to the likes of John Comyn of Badenoch for similar service are rather insignificant in comparison. Although the lands associated with the lordship of Chilham (near Canterbury) which Isabella brought into the marriage were not extensive in comparison to lands held by other Anglo-Norman magnates, the castle and manor of Chilham do seem to have been part of a barony which included the Kent manors of Lesnes, Lodenham, Northwode, Rydelyngeswelde, Kyngeston, Hatfield and Whitstable, rents in Dover, wardship of Dover castle, advowsons of churches, liberties and free customs and Chingelford manor in Essex. ${ }^{16}$ In addition, Chilham castle had been modernised and rebuilt in stone by King Henry II who spent $£ 419$ on the new structure. This was a major expenditure at a time when the average sum spent per annum on castle fortifications by the English crown was in the region of $£ 780 . .^{17}$

While the exact date of birth of Earl John de Strathbogie is also unknown, it is likely that he was very young when his father, Earl David II, died on crusade in Tunis on 6 August $1270 .{ }^{18}$ Governmental records indicate that John's affairs in Scotland were being looked after by an intermediary as late as 1282 , which may suggest that John had not yet reached his majority. ${ }^{19}$ Countess Isabella of Atholl soon re-married and her new husband was Alexander Balliol, lord of Cavers and chamberlain to King Alexander III of Scotland. The exact date of the marriage between Alexander Balliol and Isabella is not recorded, but it must have taken place before December 1276 when Alexander is described as 'lord of Chilham' in a military summons issued by Edward I. ${ }^{20}$ Geoffrey Stell has argued that during the second half of the thirteenth century the Balliol family was more frequently associated with the English court than with Scotland. This, according to him, probably stemmed from the personal support given by John Balliol to Henry III, both as a trusted royal councillor and as a military leader after 1258. ${ }^{21}$ The marriage between Isabella, countess of Atholl, and Alexander may be connected to Balliol baronial ambitions in England. It would have consolidated the links that had been carefully developed between the Balliol family 
and the Plantagenets, by providing the former with access to the inner royal family.

There is another interesting aspect to the marriage between Alexander Balliol and Isabella de Dover. An earlier relation of Alexander Balliol's, John Balliol of Barnard Castle, had married Dervorguilla of Galloway, one of the three heiresses of Alan, lord of Galloway, in 1233. Alan's brother, Thomas, had been earl of Atholl between c.1211 and c. 1237 - he married the eldest daughter of the previous earl - and this branch of the Galloway family retained the title until $1242 .{ }^{22}$ Therefore, although Alexander Balliol of Cavers was only a cousin of John Balliol of Barnard Castic, it might be suggested that the wider Balliol family, through the marriage of Isabella and Alexander, was attempting to regain some measure of the influence which the Galloway side of the family had previously enjoyed in the earldom of Atholl. If they were, this would have had important ramifications for other Scottish magnate families, such as the Comyns, who had also formed marriage alliances with the Balliol family. ${ }^{23}$

This perception is perhaps heightened by evaluating the (real or proposed) marriages of Earl John de Strathbogie. Initially, in 1286, he was clearly meant to marry a daughter of William de Soules, the hereditary butler to Alexander III. ${ }^{24}$ The Soules family had strong marital links with the family of Alexander Comyn, earl of Buchan, the leader of the political community of Scotland before his death in 1289 . However, it is impossible to tell if the marriage took place. If it did, the couple cannot have had any surviving offspring. In 1309, it was stated that John de Strathbogie had been married to Marjory of Mar. Earl David III de Strathbogie was their first-born son and the named heir to the earldom of Atholl. ${ }^{25}$ Like the de Soules family, the Mar family was connected to the Comyns through marriage. A sister of Alexander Comyn of Buchan had married William, earl of Mar, and the two families had been allies in Scottish politics during the minority of Alexander III. ${ }^{26}$ If the assumption that the Balliol and Comyn families were attempting to influence the new earl of Atholl and bring him into their political camp through marriage is correct, one reason behind this manoeuvring may have been the geographical importance of the lands which the new earl would control. The lordships of Strathbogie and Stratha'an sat between the Comyn earldom of Buchan and the 'Red' Comyn lordships of Badenoch and Lochaber, and the earldom of Atholl also had a common boundary with the lordship of Badenoch somewhere near the site of the present-day Blair castle. ${ }^{27}$ The Balliol and Comyn families would effectively bring a wide inter-connected swathe of territory into their political orbit.

It is almost impossible to assess precisely the degree of kinship Earl John felt with other members of the Plantagenet family, although he was probably named after King John I of England. The name 'John' only appears twice elsewhere among members of the Strathbogie family (at a later date) and never in the family of the earls of Fife from whom the Strathbogies were descended. However, it is clear that the English royal family recognised his status as a member of their family. In a number of documents issued by the English chancery, Earl John is addressed as 'cousin'.28 This would indicate, at least on the part of Edward I, that John was considered to be a close relation. ${ }^{29}$ The only indication that Earl John recognised this 
Plantagenet relationship occurs in the description of his trial for supporting Robert I in 1306, from English chronicle evidence. The passage in Flores Historiarum, which is thought to be both contemporary and accurate, ${ }^{30}$ states that John made an appeal for clemency to Edward I of England on behalf of their common heritage. To a certain extent this plea must have worked. Edward I conceded that Earl John should not be drawn 'because of his royal blood.' Instead, he was sentenced to death by hanging, torture and beheading. John's head was placed on London bridge and his trunk, together with flesh and bones, burned. ${ }^{31}$

\section{Lands and Associates of Earl John de Strathbogie}

There are indications that the lands controlled by the earl of Atholl in Scotland before the wars of independence were quite extensive. Apart from holding the earldom itself and the lordships of Strathbogie and Stratha'an, Earl John had also been tenant-inchicf of the lands of Saling in Clackmannanshire and Montblary in Banffshire. ${ }^{32}$ In addition, a list of grants made by King David II records a number of transactions where individuals received land forfeited by a David de Strathbogie. ${ }^{33}$ These probably refer to the forfeiture of David III de Strathbogie by Robert Bruce at the 1314 Cambuskenneth parliament, ${ }^{34}$ although, unfortunately, nothing indicates whether these lands had belonged to earlier earls of Atholl or, instead, had been granted to David III de Strathbogie in the period 1312 to 1314 by Bruce. In any event, these lands included Rothiemay in the sheriffdom of Banffshire and the barony of Dun in Kincardineshire. It should be noted that John Campbell, who was given the earldom of Atholl by Robert Bruce after Earl David III de Strathbogie returned to English allegiance in 1314, also granted properties in Kincardineshire to various people. These included the lands of Ballandro, Peattie and Inverbervie. ${ }^{35}$ However, it is again impossible to decide if these latter three lands had originally belonged to the Strathbogie earls of Atholl because there is no record of them in the primary sources before 1368 .

As far as Earl John's lands in England were concerned, it is doubtful if he ever inherited all of his parents' property. Records indicate that he received only the manor of Lesnes, which had been reserved to the widow of Richard de Dover. ${ }^{36}$ In August 1305 an order was issued to the escheator south of the Trent to deliver to John de Strathbogie the manor of Lesnes, lately held by the late wife of Richard de Dover. ${ }^{37}$ At this point the barony of Chilham was still held in capite by Alexander de Balliol, by 'courtesy' of Edward $\mathrm{I},{ }^{38}$ and this might indicate that Edward I considered Alexander Balliol a more important long-term political ally by than Earl John. English governmental records also provide a detailed account of the value of all the Strathbogie goods and lands in England. Upon the death of Isabella de Dover in 1292 , her goods were valued at $£ 96-16 \mathrm{~s}-5 \mathrm{~d} ;{ }^{39}$ in 1296 , the value of her lands was calculated to be $£ 124-17 \mathrm{~s}-10 \mathrm{~d} .{ }^{40}$ This last total did not include the value of the manor of Chingelford in Essex, which was leased to the Knights Templars at $£ 40$ per annum in $1296 .{ }^{41}$ By contrast, virtually nothing is known about the value of Atholl lands in Scotland. A sole reference dating from the 1360 s - by which time the lands of the earldom had been depleted - gives a value of six hundred marks (approximately 
$£ 400),{ }^{42}$ a figure which may have been depressed by the economic effects of the Black Death. ${ }^{43}$ However, the total value of the lands of the earl of Fife, probably the richest Scottish magnate, was assessed at $£ 432$ in 1294-95. At the time, this appears to have been three times the value of the earldom of Carrick and six times the value of the earldom of Angus. ${ }^{44}$ If all these figures are accurate, they might indicate two things: firstly, that the earl of Atholl was one of the wealthier Scottish magnates and, secondly, that land values in Scotland were not as severely depressed, in comparison to England, in the aftermath of the plague. If the valuations of the earl of Atholl's lands in both Scotland and England are added together, his potential income would have exceeded that of the earl of Fife.

Speculation regarding the possible composition of Earl John's retinue is difficult since few charters survive, but certain deductions can be made from English governmental records. After being released from the Tower of London in 1297, Earl John promised that Alexander de Meyners, Malcolm de Kilros, David le Mire and John Page would travel abroad to serve Edward I in Flanders. ${ }^{45}$ One of these men, Alexander de Meyners (Menzies), was a major Atholl landowner whose lands were mainly concentrated in Strath Tay at Weem. ${ }^{46}$ There is little information available concerning the other names in this list, although a John de Kilruthe is on record in 1342 as being a dependant of King Edward III because he had lost his lands in Scotland. ${ }^{47}$ The English governmental records for 1297 indicate that John de Strathbogie also gave mainprise for Sir John de Inchmartin so that Inchmartin could go to Scotland on the earl's affairs, although it is evident that Inchmartin was not fully trusted by the English. He alone was forced to 'swear on the evangels' that he would join Edward I in Flanders as soon as possible. ${ }^{48}$

Five days later, John de Strathbogie, Alexander de Meyners and John de Inchmartin gave joint mainprise for a large group of prisoners. ${ }^{49}$ It is immediately obvious that at least two of these captives, Sir Laurence de Strathbolgy and John de Strathbolgy (esquire) may have been related in some way to Earl John, although the exact nature of the relationship is never defined. The name of John de Strathbolgy appears in English governmental records at a later date in connection with lands near Elgin, ${ }^{50}$ and Christyn del Arde petitioned Edward I in 1306 for the lands belonging to Laurence de Strathbolgy in Sutherland and Caithness. ${ }^{51}$ These references would indicate that members of a wider Strathbogie family, possibly descended from a brother of earl John, retained interests in the north of Scotland after David II de Strathbogie became earl of Atholl. Another four prisoners - Sir John de Inchmartin, Sir Henry de Inchmartin, Sir John de Camburnon (Cambron) and David de Cambernon - belonged to families who, apart from holding lands of the crown outwith Atholl, also held lands in Atholl directly of the earls. ${ }^{52}$ In fact, members of the Cambron family are found witnessing charters of David de Hastings, earl of Atholl between c.1244-47,53 which may indicate that the family had been connected to the earldom over an extended period of time. ${ }^{54}$ Another member of the family, Sir Robert Cambron de Balemely, was sheriff of Atholl in $1296^{55}$ and witnessed at least one charter issued by Earl John. ${ }^{56}$ The records of the Great Cause include a list of people who swore fealty to Edward I of England in 1291. Among these names, under 
the sub-division armigeri, is the name of Johannes de Cambron. ${ }^{57}$ If he is the same person as the Sir John de Cambron mainprised by John de Strathbogie in 1297, this might suggest that he was the personal armour-bearer to Earl John of Atholl and a member of his inner retinue.

Another of the prisoners, William Bron, may also have belonged to a family closely connected to the earldom of Atholl. ${ }^{58} \mathrm{~A}$ William Brun witnessed charters of Thomas (of Galloway), earl of Atholl, in the early thirteenth century and a Thomas Broune was associated with Earl David IV de Strathbogie in the early $1330 \mathrm{~s}^{59}$ If this Thomas Broune is the same person that was pardoned by Edward II of England in $1321,{ }^{60}$ the family also held lands in the Borders, probably near Berwick. ${ }^{61}$ Some of the other names in the list of prisoners appear to be of Strathearn origin. For example, Sir William de Moravia was married to a daughter of the hereditary stewards to the earls of Strathearn, the Logies, c.1284 and was granted the lands of Tullibardine. Malise de Logy, second son of the last Strathearn steward (Malise de Logie c.1233 to 1284), is also clearly of Strathearn origin. ${ }^{62}$ It is perhaps unusual that Earl John de Strathbogie was mainprised for Strathearn landowners. By early 1297 Earl Malise of Strathearn had been pardoned by Edward I and it might be asked why he did not stand surety for his own adherents, particularly as he had personally sworn fealty to the English king. ${ }^{63}$ However, according to Cynthia Neville, Malise de Logie (the son) had resigned all his rights to various lands in Strathearn shortly after $1284 .{ }^{64}$ If so, it is possible that Logie had entered into a tenurial relationship with the earl of Atholl after this date, although this suggestion would not account for the presence of Sir William de Moray in the list of prisoners. What is clear is that many of the names on this list can be found in both earlier and later contexts in connection with different carls of Atholl. This implies that there was a select group of lesser landholders within the carldom from which representatives were appointed to serve in a particular earl's retinue.

There is one other group of people who appear in the primary sources in connection with different Strathbogie earls of Atholl. ${ }^{65}$ These are various men who are given the designation 'de Atholl', but whose genealogical connection, if any, to the Strathbogie family is difficult to ascertain. It is equally impossible to prove that these men were related to one another, although the relative scarcity of the designation 'de Atholl' might suggest that they were. Chronologically, the first of these men to appear in English governmental records is Macbeth de Atholl, esquire, who was imprisoned in Wallingford castle in 1296, probably for fighting against Edward I at the battle of Dunbar. ${ }^{66}$ However, it would appear that there is no record either of Earl John giving surety for Macbeth's future good behaviour, or of Macbeth's release from jail in 1297. Later, between 1307 and 1311, a Donald de Atholl appears in the English records on four occasions, coinciding with the periods when the earls of Atholl were in English allegiance. Amongst other things, Donald acted as a messenger carrying privy seal letters for Edward II in Scotland. ${ }^{67}$ The final member of this group is Robert de Atholl who was closely associated with both the sons of Earl David III during the 1330s and who appears to have held lands in England of Earl David IV in 1335.68 
Two of these men, Donald and Robert, also appear under the designation 'Lasceles'. This name might suggest a Fife origin which would give them a connection to the Strathbogie family. However, the main line of the family of Lasceles in Fife ended in a female heiress, Marjorie de Lasceles, before 1250. She married first, Peter de la Hay and later, Richard de Moravia of Culbin in Moray. According to Barrow, these marriages led to a permanent division in the Fife barony of Naughton/Forgan. ${ }^{69}$ Marjorie's second marriage suggests another possible point of contact between the Lasceles and Strathbogie families in the north-east of Scotland. Interestingly, the designation 'de Atholl' also appears in Scottish sources during the reign of King David II. ${ }^{70}$ In these instances the name always refers to members of Clann Donnchaidh, or Robertsons, who were granted lands in Perthshire by the earl of Fife in the 1340s, including Fortingall, Strath Braan and Loch Tay. ${ }^{71}$ However, as yet there is no direct evidence to prove that the three men given the designation 'de Atholl' in the English sources, and who are connected to the Strathbogie earls of Atholl, were related to the kindred of Clann Donnchaidh.

\section{High Politics}

Given the social links between Earl John and the Balliol-Comyn political faction in Scotland it is perhaps surprising to find Earl John's name among the forty auditors nominated for Robert Bruce (the Competitor) at the outset of the Great Cause - to decide who would be the next king of Scots - in $1291 .{ }^{72}$ Why he adopted this political stance is unclear, although one explanation may be that the two families were related by marriage: the grandson of Robert Bruce (the Competitor), the future Robert I, was married to a sister of earl John's wife. ${ }^{73}$ Although Earl John was one of the eleven Bruce auditors - John de Inchmartin was another - who did not vote against their preferred candidate on 6 November $1292,{ }^{74}$ he must have become reconciled to the elevation of John Balliol as king of Scotland before 1296. Unlike any members of the Bruce family, Earl John appended his seal to the Franco-Scottish treaty of 23 April 1296, ${ }^{75}$ and he had also ignored Edward I's earlier summons for military service against the French. ${ }^{76}$ Earl John fought at the battle of Dunbar, ${ }^{77}$ was captured, and sent to the Tower of London. ${ }^{78}$ All these facts indicate that at some point between 1292 and 1296, John de Strathbogie distanced himself from the general Bruce family policy of non-cooperation with King John Balliol.

Earl John is again found fighting against the English in 1299 when he joined in a raid against English-occupied lands in southern Scotland, ${ }^{79}$ and in 1300 he was appointed sheriff of Aberdeen by John Comyn of Badenoch. ${ }^{80}$ This appointment suggests that he was trusted by the Balliol-Comyn government. However, shortly afterwards, Earl John disappears from the primary sources for almost four years. It is well known that Robert Bruce, the future Robert $I$, switched allegiance in late 1302, and it is likely that Earl John's step-father, Alexander Balliol, had also joined Edward I at an even earlier date. ${ }^{81}$ All that is known about Earl John is that by 19 January 1304 he had sworn fealty to Edward I and was petitioning the king about obtaining entry into the manor of Lesnes in Kent. ${ }^{82}$ It is difficult to decide what caused this change of allegiance which predates the general surrender of Scots to Edward I at 
Strathord on 9 February $1304 .{ }^{83}$ In contrast to Alexander Balliol, most of whose lands in the Borders were under English occupation, and Robert Bruce, who was in danger of losing control of the caput of the earldom of Carrick, Turnberry, to an agent of the French under the terms of the peace of Asnières, ${ }^{84}$ it could be argued that Earl John had very little to lose. At this point he had probably never had seisin of any of his mother's lands in England, and the earldom of Atholl does not seem to have unduly suffered from English occupation or harassment between 1296 and 1304.85 Therefore, it might be suggested that if Earl John did switch sides at the same time as the future Robert I, it may have been for personal reasons between the two men rather than in an effort to preserve his patrimony.

Edward I might have felt justified in remaining suspicious of Earl John in 1304. After all, John had previously sworn allegiance to him and undertaken military service in Flanders, ${ }^{86}$ before rejoining the Scots to fight against him in 1299.87 However, if Edward I distrusted John, he concealed it well. He re-appointed him as sheriff of Aberdeen. In February 1304, acting in concert with some Aberdeen burgesses, Earl John successfully intervened in this capacity on behalf of two other Aberdeen burgesses who had been imprisoned at York. ${ }^{88}$ By November 1304, Earl John had also been appointed as the Edwardian warden and justiciar for Scotland between the Forth and Orkney ${ }^{89}$ and was entrusted with building a new castle for Edward I beyond the Forth..$^{90}$ It may not be a coincidence that Earl John reappears in the north-east during this period: in late 1302 Robert Bruce had been granted the wardship and marriage of the heir to the earldom of Mar by Edward I.91 This grant would, in effect, also have given command of Kildrummy castle to Bruce and meant that he controlled a strong strategic position from which the Comyn lands of Buchan and Badenoch could be threatened on behalf of Edward I. Consequently, it might be surmised that the re-appointment of Earl John to the sheriffdom of Aberdeen was a similar strategic move by Edward I. In fact, there is some evidence to suggest that it was, and that Earl John did take an active role in opposing the Balliol-Comyn faction in Scottish politics during this period. In 1304 he wrote to Edward I in a successful attempt to block the appointment of Sir Alexander Comyn as warden of Aboyne castle. 92

On 2 August 1305 Earl John inherited, and performed homage for, one of the manors which his family owned in Kent. ${ }^{93}$ This seems to have been the first occasion upon which he swore fealty to Edward I for Atholl lands in England. Three weeks later, the English chancery issued John with a protection for two years so that he could travel to Scotland. ${ }^{94}$ At this point, Edward I did not know that Robert Bruce was going to murder John Comyn of Badenoch, and consequently the English king could not have expected Earl John to become involved in an uprising. If Earl John departed for Scotland shortly after the protection was issued, he left England before the parliament of September 1305 which finalised the ordinances for the government of Scotland. Although the ordinances removed Earl John from the positions of warden and justiciar to which he had been appointed by Edward I in 1304, he was included in the new governor of Scotland's council. Of course, probably the most radical new development in the ordinances was that Scotland was no longer referred 
to as a 'realm', but as a 'land'. 95 The future Robert I had been involved in the preliminary negotiation of the ordinances and, if Earl John was closely associated with Bruce in England and Scotland between 1302 and 1305, it is likely that this new development in the definition of Scotland was as acceptable to him as it was to Bruce.

Within six months of the ordinances being agreed, Robert Bruce made an open bid for the Scottish crown and initiated a civil war in Scotland that was to last for at least three years. The available evidence strongly suggests that Earl John did not initially support Robert I after the murder of John Comyn: an incomplete anonymous letter, 'News of the earl of Carrick', and probably dateable to a few weeks after the murder, states that the earl of Atholl and the earl of Buchan: 'have agreed and swom together to remain......... [rest incomplete]. ${ }^{196}$ One interpretation of this evidence might be that Earl John, apparently one of Bruce's closest allies, was unprepared for the sudden violence of 10 February 1306. If, as according to Barrow, Bruce was working to 'a pre-arranged plan', 97 why was Earl John excluded from this radical course of action? In any event, Earl John must have changed sides quite quickly and thereafter consistently supported the new king throughout the first few months of his reign before being captured in Ross-shire in September 1306. Much has been made of Edward I's reaction to the renewed Scottish unrest, particularly with regard to the executions of Simon Fraser and John de Strathbogie. Barrow, for example, refers to their killing in terms of 'slaughter and persecution. ${ }^{198}$ Nevertheless, it is important to remember that Bruce had murdered the leader of the political community in Scotland, claimed the Scottish throne, which Edward I believed he himself held, and disrupted the negotiated settlement of 1305 for the government of Scotland. Equally, Simon Fraser, for example, had been a knight in Edward I's personal household. If Edward I was aggrieved about Fraser's actions in supporting Bruce, there can be little doubt about how harshly he regarded the actions of Earl John, a member of his own family, who had recently sworn fealty to him. In his anger at the betrayal, Edward I may have ignored the fact that, with the exception of three short occasions, Earl John had been closely allied to the Bruce family from the outset of the Great Cause. Although Earl John was occasionally prepared to compromise with the leaders of the political community in Scotland, he consistently chose to uphold the Bruce cause. Earl John, it would seem, was a man whose personal relationship to his brother-in-law was more important than his marital links to the Comyn family, and his blood-relationship to the Plantagenet dynasty.

Earl David III (c.1290-1326)

Marriage, Lands, Associates and Baronial Politics, 1307-1312 and 1314-1326

It is difficult to ascertain exactly how old earl David III was in 1306 when his father was executed. No source gives his exact age at any point in his life. However, it is fairly certain that his heir, Earl David IV, was born in 1307, and this indicates that Earl David III would have been at least fourteen years old by this time. Therefore, he must have been born sometime before 1293. When Earl John was released from 
prison in 1297, he was required by Edward I to deliver his eldest son as hostage for his future good behaviour. ${ }^{99}$ If it is assumed that Edward I would not have risked the life of an infant by forcing it to undertake a long journey, it is likely that the young David III de Strathbogie was born before 1293, possibly c.1290. Earl David III also had two surviving siblings: a brother, John II, is mentioned in $1316^{100}$ and a sister, Isabella, survived until c.1329.101 Like his father, Earl David III married into the leading family of the Scottish political community. His wife, Joan Comyn, was the oldest surviving daughter (born in 1292) ${ }^{102}$ of John II Comyn of Badenoch, and their wedding might confirm what seems to be a pattern of Strathbogie-Comyn marriages. The marriage could have been contracted by Earl John before his death in 1306, possibly while he was part of the Comyn administration in Scotland during 1302. However, given the birth-date of Joan Comyn it is unlikely that any final ceremony would have taken place before 1306.

Earl David III de Strathbogie may have been in Scotland during the period of his father's capture and execution. His younger brother John was certainly there, although he cannot have been travelling with his parent because he was not captured in Ross-shire along with the rest of his father's party. On 25 August 1306 Malise, earl of Strathearn, and John de Inchmartyn were mainprised by Edward I to produce John II de Strathbogie, the brother of David, on pain of forfeiture of their lives and goods. ${ }^{103}$ The terms of this agreement seem rather severe, indicating that Edward I urgently needed to gain physical control of one of earl John's children. Although Edward may merely have been worried about a young relation being stranded in a war-zone, his concern perhaps reflects a determined effort to stop Robert Bruce gaining control of John II de Strathbogie. At any rate, it seems that the new earl of Atholl, David III de Strathbogie, was not within Edward's reach. This last perception is strengthened by the contents of an anonymous document written by someone close to Edward I, dated 15 May 1307. This reports that David had come into the king's peace, 'in what form, unknown. ${ }^{104} \mathrm{By}$ its very nature, the phrase 'come into the king's peace' would suggest that David had not been in Edward I's peace before May 1307.

There is a curious reference to a siege of Brechin castle in 1307 which occurs only in Barbour's Bruce. Barbour states:
And schyr David off Breychyne
Fled till Brechyne his awine castell
And warnyst it bath fayr \& weill,
Bot ye erle off Atholl Dawy
His sone yat wes in Kyldromy
Come syne and him assegyt yar. ${ }^{105}$

This passage seems to imply that Earl David was allied to Robert Bruce since David de Brechin is known to have sided with Edward I in 1307. However, the obvious problem with this excerpt is that Barbour places it after the battle of Slioch on Christmas day 1307.106 According to English sources, Earl David had already returned to English allegiance by this time. Furthermore, a letter written by Sir 
Duncan de Frendraught, sheriff of Banff, to Edward II clearly states that Earl David was fighting against Robert I at Slioch. ${ }^{107}$

These problems of chronology have led A.A.M. Duncan to suggest that the date of the Brechin siege was mis-placed by Barbour. According to Duncan, the siege took place in 1306 and it was Earl John I de Strathbogie that was the aggressor, because Earl David III was in English allegiance until 1312.108 Alternatively, MacDiarmid and Stevenson suggest that the siege took place after 1312 when Earl David was an adherent of Robert I. ${ }^{109}$ Obviously, both these suggestions presuppose that Earl David was in English allegiance between 1306 and 1312. However, as MacDiarmid and Stevenson point out, the chronology in this section of Barbour's work is seriously awry. Therefore, it might be asked if a siege of Brechin castle did perhaps occur in 1307, but before David returned to English allegiance. Edward I's anonymous informant of 1307 also mentions the name of James Douglas. Väthjunker concluded that Douglas had been hiding somewhere between Glen Trool and Glen Ure and was being pursued by Aymer de Valence. According to her, Douglas had made overtures towards the English forces to surrender but had changed his mind when those forces withdrew, possibly after an engagement at Loudon Hill. ${ }^{110}$ If this argument is correct it might be asked whether David was also in this area as an adherent of Robert Bruce. While there is no certainty of this, if Strathbogie was fighting for Bruce during this period it would have been logical for him to have surrendered to Valence. Joanna Comyn, David's wife, was Aymer de Valence's niece. ${ }^{\text {II }}$

There could have been a number of different reasons behind David's change of allegiance. Obviously, the danger of being trapped and killed by English troops may have been a primary motivation and it is also possible that David was reluctant to fight against the representative of his cousin, Edward I. More importantly perhaps, David could have been aware that Edward I had granted the earldom of Atholl to Ralph de Monthermer sometime before June 1307. Concern about retaining his family lands in Scotland, and his position in society as an earl, probably provided a greater motivation for changing sides, particularly if he thought that Bruce's attempt to usurp the Scottish throne was going to fail. If this was the case, his change of allegiance worked. On 24 June 1307 David agreed to a proposition from Edward I whereby he would buy back his earldom of Atholl for ten thousand marks, half of which would be paid by Edward I. ${ }^{12}$ David, together with Aymer de Valence, John Mowbray, Alexander Abernethy, John Comyn, William Cardoill, David de Brechin, Alexander Balliol, Edmund Comyn and John Hastings, agreed to become jointly bound to pay the remaining five thousand marks to Ralph de Monthermer in yearly instalments. 113 Obviously, David could not raise the money on his own and the number of people that stood surety with him might indicate that he was in a desperate financial position. Four years later, Monthermer complained to Edward II that he had not yet received any of the money due to him from Earl David III. ${ }^{114}$

After 1307 both David and his brother John II served the English crown in a military capacity on a number of occasions, both on the Scottish border and in the keeping of Dundee castle. ${ }^{115}$ Like any other magnate, David might have expected 
that he would be rewarded for services to the crown, particularly as he was a 'cousin' of Edward II. Indeed, governmental records show that David was granted some new lands in England, namely the ex-Templar manors of Suthcave and Etton in Yorkshire. ${ }^{116}$ The date of the original grant of these properties is unknown, although it must have been before February 1312 when the keepers of the Templar lands in Yorkshire were ordered by Edward II to give David, in addition to the manors already in his possession, all the crops, ornaments and utensils of an unnamed chapel. ${ }^{117}$ However, it is clear that David had no chance of regaining control of any of the lands associated with the lordship of Chilham after 1307. The manor of Lesnes, probably the only part of the lordship of which his father, Earl John, had seisin, had been forfeited and granted to Margaret, queen of England, in $1306^{118}$ and the earl's right of presentation to Rydelyngeswelde church in the diocese of Canterbury was also in royal hands by this date. ${ }^{119}$ The remainder of the lordship of Chilham was controlled by Alexander Balliol. Upon Balliol's death in 1311, Edward II then granted the barony to one of his trusted councillors, Bartholemew de Badlesmere. ${ }^{120}$

There is little doubt that Earl David III's landed wealth declined drastically in Scotland too between 1314 and 1326. All his lands in Scotland were forfeited by Robert I at the Cambuskenneth parliament of 6 November 1314. ${ }^{121}$ The earldom of Atholl was granted to Mary Bruce, a sister of Robert I, and her husband, Sir Neil Campbell. Their son, John Campbell, retained the earldom until he was killed at Halidon Hill in 1333.122 The lordship of Strathbogie went to the Gordon family, ${ }^{123}$ the lordship of Stratha'an to the earl of Lennox ${ }^{124}$ and smaller properties went to the Abernethy and Wiseman families. ${ }^{125}$ The barony of Dun (Kincardineshire) and the lands of Mughrum and Carnesvole in Wigtownshire, among others, were eventually given to Alexander Bruce, the illegitimate son of Isabella de Strathbogie and Edward Bruce. ${ }^{126}$ This pattern of granting forfeited lands to loyal supporters of Robert $I$ has already been investigated in respect of the earldom of Buchan. ${ }^{127}$ However, unlike Buchan, the earldom of Atholl was not completely dismembered.

One reason for this may be that Robert I gave the earldom to his sister and Neil Campbell neither of whom, as far as can be ascertained, had any previous connection with Atholl. In turn, it is likely that the new Campbell earl of Atholl also appointed his own retainers into positions of responsibility within the earldom. Dougal Campbell who paid a sum of money from the balliary of Atholl in 1326, may have been one of them. ${ }^{128}$ Meanwhile, other members of the king's family also received new lands in Atholl. Before 1326 Robert Bruce, lord of Liddesdale, illegitimate son of Robert I, granted lands in the Abthen of Dull to Sir Robert Menzies. ${ }^{129}$ The introduction of new officials and tenants-in-chief meant that existing internal patterns of responsibility, social bonds of kinship and patronage within the earldom were altered. A conscious effort on the part of Robert I to minimise these disruptions may explain why the Menzies family, who were already one of the major landowners in the earldom, were not affected by the forfeiture of Earl David III. Their lands were augmented through a series of grants from Robert I and, by 1329, the Menzies estates stretched almost continuously from Aberfeldy to Loch Lomond. ${ }^{130}$ This suggests that 
Robert I was attempting to preserve some sort of continuity in the pattern of landholding in the earldom. If he was, the effort probably failed and stronger measures were needed. Two charters dating from the end of the reign of Bruce are quite unequivocal in calling Isabella de Strathbogie, sister of earl David III, 'countess of Atholl'. ${ }^{131}$ Assuming that these references are not both scribal errors, the most obvious explanation for Isabella's title is that she had married John Campbell, son of Mary Bruce and Neil Campbell, before 1329. It is likely that John Campbell was not born until after the period 1312 to $1314,{ }^{132}$ and his bride must have been a generation older than him and may have been nearing the end of her child-bearing capability. While the possibility that the couple were in love cannot be discounted, it seems more likely that their marriage was a deliberate attempt to 'legitimise' the new Campbell holders of the earldom, at least in the minds of local residents. By connecting them directly with the previous incumbents, a Campbell-Strathbogie marriage would have made for a sense of continuity with the past. It may also indicate that some sections of Atholl society were not completely reconciled to the forfeiture of Earl David III de Strathbogie.

Although Earl David III had lost his lands in Scotland after 1314, the unexpected deaths of both the son and grandson of John Comyn of Badenoch, by October $1316,{ }^{133}$ left David's wife, Joanna, and her sister, Elizabeth, as co-heiresses to the Comyn of Badenoch lands in Scotland and England. Joanna's share of this inheritance in England, according to an inquiry of 1330, was four Northumberland manors worth $1376-14 s-3 d$ (see Appendix 2). In Scotland, David also now had a claim - in right of his wife - to the lordships of Lochaber and Badenoch and other Comyn properties in southern Scotland. ${ }^{134}$ Although the actual value of the Comyn properties in England may have been negligible in 1316, after two years of Scottish raiding south of the Border, their combined potential value was approximately three times that of the lordship of Chilham. This inheritance, if it was producing any income, must have provided a welcome boost to David's finances. His wealth was increased by other awards of land. Shortly after Bannockburn, David was granted the manor of Eylesham in Gloucestershire, ${ }^{135}$ the manor of Honedon in Suffolk and a number of other lands in Norfolk. ${ }^{136}$ This was later augmented by a grant of all knights' fees and advowsons of churches belonging to the Norfolk manors. ${ }^{137}$ All of these grants were probably awarded to David because Edward II had promised in October 1314 to provide him with lands equal in value to the lordship of Chilham. ${ }^{138}$

Of course, with the exception of Eylesham, the rest of these lands and privileges had previously belonged to Aymer de Valence, earl of Pembroke, and after Aymer's death in 1324 Earl David III inherited these properties in right of his wife. ${ }^{139}$ However, in other respects the king was more generous, which may indicate a change in English royal attitudes towards David after 1314. In 1316, shortly after being issued with a safe-conduct to go to Scotland, ${ }^{140}$ David was permitted to keep all plunder from Scotland and the ransoms of any Scottish knights that he could capture. ${ }^{141}$ It is also evident that David had not forgotten about the lordship of Chilham. In March 1315 he petitioned Edward II for the return of the lordship which, he claimed, had been taken from his family in violation of the English ordinances of 
1311. ${ }^{142}$ For David to have claimed this is somewhat surprising. He must have known that his father had been forfeited in 1306 and it might be asked why he would have wanted to waste money on legal fees advancing a false claim. However, by 1315 the earl of Lancaster was effectively running the English government and actively enforcing the ordinances. ${ }^{143}$ As a new adherent of Lancaster's, David may have been hoping for a sympathetic hearing. ${ }^{144}$ On this occasion he was not successful. He did not regain the lordship of Chilham until $1321^{145}$ when, as a further sign of royal favour, he was pardoned from diverse scutages for the Lordship. ${ }^{146}$ Earl David's long quest to regain the lordship of Chilham perhaps emphasises the importance of property and land, no matter how small, to the aristocratic mindset of this period.

It was, however, the blood relationship between Joanna Comyn and Aymer de Valence that provided Earl David III with his largest source of income. Earl Aymer's lands and property, although split among a number of heirs, were extensive. David's share of the inheritance in right of his wife, which probably amounted to approximately $£ 1000$ in value, included properties located in England, France and Ireland (see Appendix 3). Furthermore, the heirs of Aymer de Valence were pardoned of any debts which he owed Edward II. ${ }^{147}$ An approximate calculation of David's potential income after 1324 would be in the region of about $£ 1500$, perhaps three times the value of the earldom of Atholl. More importantly perhaps, after 1324 David was an international landholder with the attendant difficulties of performing homage to two different kings, of England and of France, for his lands. ${ }^{148}$ Unfortunately, it is difficult to assess how this new status would have influenced his actions. By 1326, approximately one year after Edward II had commanded him to partake in an expedition to Aquitaine, David was dead. ${ }^{149}$

\section{A Scottish Interlude, 1312-1314}

Earl David III must have returned to Scotland before 29 October 1312 when the word 'Atholie' appears in the witness list of a Scottish-Norwegian treaty. ${ }^{150}$ After 26 February 1313 he regularly appears in royal witness lists as David comite Atholie constabulario nostro Scocie, usually witnessing after Edward Bruce and before Thomas Randolph, earl of Moray. ${ }^{151}$ This is a clear indication that David had not only regained his earldom but had also been given the title of 'constable'. This position had been granted to the Hay family before March $1309^{152}$ and it is possible Robert I stripped them of this title so that he could use it as an inducement to encourage David to change sides. Alternatively, the earl may have made its bestowal a condition of his return to Scotland. Either scenario demonstrates the willingness of Robert I to accommodate magnates who remained outwith his allegience, like the earls of Mar, Angus, March and Fife.

Although Earl David's change of allegiance could have been partly due to Edward II's refusal to grant the lordship of Chilham to him, the timing of David's return may be significant for another, more important, reason. Recently, A.A.M. Duncan has convincingly argued that the Cambuskenneth statute of November 1314, which forfeited anyone not in Robert I's peace, was proclaimed one year earlier at 
Dundee in 1313. In effect, everyone was given one year's grace to come into the Robert's peace or be forfeited of their lands in Scotland. ${ }^{153}$ Further proof of his argument is found in the text of a letter issued in 1323: '...David of Hastings [Strathbogie] forfeited the above lands in Atholl and their appurtenances [coming] against our peace, and lost them by the judgement that was given out in our parliament held at Cambuskenneth [1314] by the consent of all the Church and the people carrying out justice, being one amongst others who were not in our peace at the said parliament. ${ }^{154}$ It is possible that Earl David had foreknowledge of the Dundee proclamation and that his switch of allegiance to Bruce in late 1312 was an attempt to preserve his patrimony in Scotland and his rank as an earl. By then it would have been obvious that Robert I had won the civil war in Scotland and had succeeded in establishing a new royal dynasty.

Throughout his short time in Scotland, David seems to have fully supported Robert I. Although he did not figure prominently in the later works of Fordun, Barbour or Bower, there is some evidence from an English source that he was a useful asset to Bruce. The town of Perth was not recaptured by the Scots until early 1313 and while the three Scottish chroniclers are agreed that the assault was personally led by Robert $I,{ }^{155}$ Sir Thomas Gray of Heton provides the information that it was led by Earl David III. ${ }^{156}$ To date, historians have been divided in their treatment of this information. Barrow virtually ignores Gray's commentary ${ }^{157}$ and Duncan gives it a cursory discussion before dismissing it because the three Scottish sources disagree with Gray. ${ }^{158}$ Both these assessments ignore the fact that Sir Thomas Gray's father was a veteran of Bannockburn and a landowner in Northumberland, as was Earl David III. These two men could easily have been acquainted. Not only did Gray have access to first-hand information, he also compiled his account at a relatively early date, between 1355 and 1359. Therefore, it is perhaps less likely that the information would be corrupted. It should also be noted that Sir Thomas Gray's lord in Northumberland was Sir Henry Beaumont, father-inlaw of Earl David IV de Strathbogie: Gray potentially had access to a third independent source of information on which to base his work. ${ }^{159}$ The immediate problem is deciding whether three Scottish sources have written the role played by Earl David III at Perth out of history and awarded the plaudits to their hero or, whether Sir Thomas Gray's information is more trustworthy. Given some of the proBruce biases in Fordun and Barbour already evaluated by other historians, ${ }^{160}$ it is possible that Gray may be providing the more accurate account. Of course, these proBruce biases in Scottish sources make it difficult to verify Barbour's explanation for David's switch of allegiance on the eve of Bannockburn. According to the poet, the earl abandoned the Scottish side because his sister, Isabella, was either going to have, or already had, an illegitimate child by Edward Bruce. As if this were not bad enough, Edward Bruce, unable to keep his libido under control, was now having an affair with the sister of the earl of Ross and ignoring the pregnant Isabella de Strathbogie. In a fit of pique, Earl David attacked a Scottish supply depot at Cambuskenneth, killing Sir William Airth, and then deserted to the English, carrying the stolen food with him. ${ }^{161}$ 
According to Duncan, there are two possible explanations of this testimony: either that Isabella de Strathbogie had been engaged to Edward Bruce but discarded for Isabella of Ross, or that Edward Bruce was resisting pressure to divorce Isabella of Ross, marry Isabella de Strathbogie, and legitimise their child. ${ }^{162}$ Both explanations are plausible and it is difficult to evaluate how David would have reacted to either of these scenarios. Certainly though, David's sister does not seem to have been particularly disconcerted by her supposed rejection. She remained in Scotland and became countess of Atholl. Her son, Alexander Bruce, eventually became earl of Carrick before being killed in 1333.163 There is, however, one very important point to remember regarding the historicity of Barbour's account: his work is a romance. The author freely admits to this. Contemporary readers of any work of this genre both looked for, and expected, escapism in the form of descriptions of chivalric deeds. ${ }^{164}$ This should be enough to make any historian suspicious about a passage concerning knightly reactions to a pregnant lady in distress.

But there is another, potentially greater, problem with Barbour's account. If the date of Earl David III's desertion provided by Barbour is correct - the night of 23-24 June 1314 - fighting had already occurred between the two sides and, as constable of the Scottish army, David should have been playing a major role in leading the Scottish infantry. At the very least, it can be argued that he should have commanded one of the Scottish divisions. ${ }^{165}$ If he did, his role has been edited out of Barbour's account of the battle (David also fails to appear in any English sources describing the conflict). Of course, this problem is exacerbated by the fact that Scottish and English sources disagree about the number of divisions on the Scottish side and their leaders. If Cameron's argument that Barbour invented a fourth Scottish infantry division, to provide a role for Douglas and Stewart during the battle, is correct, the other three named Scottish infantry commanders are Robert I, Edward Bruce and Thomas Randolph. ${ }^{166}$ If Robert I did not assign earl David a commanding role before the battle, would David have regarded this as a personal insult? Very likely; and the welldocumented rivalry between the two constables in the English army at Bannockburn, Gilbert de Clare and Humphrey de Bohun, could be used as a parallel in this respect.

In retrospect, deserting the Bruce cause was a crucial step for Earl David to take. After the Cambuskenneth statute of November 1314, Scottish landowners were forbidden from holding lands in England, and English landowners were likewise prohibited from holding lands in Scotland. Legislation of this nature was unprecedented in Anglo-Scottish relations and it created a new group of disgruntled landowners, the 'disinherited', based in England, who pressed to regain their lands and titles in Scotland for decades to come. ${ }^{167}$ Given the co-operative pattern of Anglo-Norman landholding between the two realms over the previous hundred years they had every right to do so. After all, the situation was not of their making but had been forced upon them by Robert I. Nevertheless, being disinherited by Robert I in 1314 does not seem to have prevented Earl David from interfering in Scottish matters. A curious safe-conduct dated 11 November 1323 gives protection for a Scot, Taffyn de Loran, to come into England to speak with Earl David III. ${ }^{168}$ Evidently, Taffyn was not entirely trusted; he was only allowed to come a distance of ten 
leagues into England from the Marches. Taffyn was probably a member of the de Lornyn family who had been tenants of the Strathbogie earls of Atholl for a long time. ${ }^{169}$ Unfortunately, it is virtually impossible to tell what this meeting was about, although it is likely that it had something to do with the earldom of Atholl. A letter dated to shortly after July 1323 records that Dunfermline abbey had obtained entry to lands in Perthshire which it had previously rented to David III de Strathbogie. ${ }^{170}$ The letter was the result of a lawsuit which, according to Barrow, was between John Campbell earl of Atholl, and the abbot of Dunfermline. ${ }^{171}$ However, John Campbell would probably still have been a minor in 1323 and he was not named in the document in question. ${ }^{172}$

It is peculiar that the abbot of Dunfermline waited nine years after the forfeiture of earl David to re-establish his rights to these Perthshire lands. Had Earl David's lands been forfeited to the crown, Robert I could have retained control of the properties in the intervening period. However, it is clear that these particular properties were not in the possession of the king. The abbot claimed that, 'nor did he have a tenant whom by law he was bound to recognise.' This phrase suggests that the abbot had an illegal tenant, possibly Earl David, and that money from the properties was being diverted to him in England. After 1320 there are a number of recorded instances of people in the allegiance of Edward II going to Scotland to 'treat upon their lands and affairs there'. ${ }^{173}$ Some of these claims may have arisen because legislation enacted by Robert $I$ in 1318 extended the parameters of mort d'ancestor whereby pursuers could trace their right to succeed from an earlier generation. ${ }^{174}$ Obviously, this new legislation did not apply in this instance because it was the abbot who initiated the lawsuit. It might be asked, however, whether the terms of perpetual disinheritance in the Cambuskenneth statute ${ }^{175}$ contained a legal loophole. For example, the statute may not have distinguished between lands held directly of the crown and lands rented from another tenant-in-chief or dowers. If it did not, this might explain some instances where its terms could be challenged and David may also have been able to retain some income from his Atholl lands.

Earl David also seems to have been involved in the political consequences of the 'Black Parliament' in $1320^{176}$ for he was commanded by Edward II to receive into his peace some of those who had clearly been involved in the conspiracy. ${ }^{177}$ This might indicate that David's involvement in this affair was marginal. However, at least two of the conspirators who were executed, John Logie and Richard Brown, may have belonged to families that had been associated with Earl John de Strathbogie in the late thirteenth century. This perception is strengthened by another entry in English governmental records which shows that a further three members of the Brown family, Thomas, Alexander and William, also fled to England in early 1321. ${ }^{178}$ While this does not prove that Earl David was directly involved in the plot against Robert I, the known relationship between the Brown family and the earls of Atholl might suggest that he was.

\section{High Politics in England}

There is no evidence that Earl David III was involved in governmental politics in 
England before 1312, although, subsequently, he was summoned to parliament on six occasions between 1322 and $1326 .{ }^{179}$ What is clear is that upon his return to England David attached himself to the household of Thomas of Lancaster. In 1319 David was in Lancaster's retinue at Berwick with two bannerets, four knights and thirty-three men-at-arms. ${ }^{180}$ For this service he received a list of grants from Lancaster for life. ${ }^{181}$ It is likely that David's adherence to Lancaster occurred after Lancaster had gained control of the government at the York parliament of 1314, although it is equally possible that the two men could have had contact before 1312 through Aymer de Valence, the uncle of Earl David's wife. ${ }^{182}$ Of course, David must have been in a desperate position after Bannockburn. He had effectively lost his lands in Scotland and had no visible means of support in England. While he may have received some measure of help from Valence, his adherence to Lancaster may also have been a recognition that he did not expect much in the way of patronage from Edward II. However, Lancaster failed to form a stable government after 1315, and until the treaty of Leake in August 1318, Lancaster and Edward II were on the brink of initiating a civil war in England. Although there is little evidence pertaining to David during these years, he must have remained in the Lancastrian camp: on 22 October 1318 a royal pardon was issued to him as an adherent of the earl of Lancaster. ${ }^{183}$

After the treaty of Leake, Earl David III seems to have maintained a political foothold in both rival camps: royal and Lancastrian. By 1320 he was clearly working with Andrew Harcla, earl of Carlisle, for Edward II, ${ }^{184}$ while maintaining an armed retinue for the earl of Lancaster. ${ }^{185}$ This must have been difficult as relations between Edward II and Lancaster continually deteriorated between 1318 and $1321 .{ }^{186}$ In fact, there is an indication that David was not entirely trusted by Edward II during this period. On 12 November 1321 he was ordered not to attend a meeting illegally convened by Lancaster. ${ }^{187}$ However, shortly after this writ was issued David must have finally abandoned Lancaster and joined forces with Edward II for good. On 28 November 1321, David was granted the long-sought lordship of Chilham, previously held by Bartholomew de Badlesmere. ${ }^{188}$ It is likely that Badlesmere's change of allegiance from Edward II to Lancaster in September 1321 provided David with a sudden political opportunity to regain his patrimony in England. If this interpretation is correct there must have been an element of risk involved. As it happened, Earl David III took full advantage of the disintegration of the Lancastrian cause after the battle of Boroughbridge in 1322 and, perhaps ironically, was one of the judges who pronounced sentence on both Lancaster and Badlesmere. ${ }^{189}$ This surely demonstrates a very high level of political ingenuity. It is clear that Edward II was grateful for David's sudden change of allegiance in late 1321. From this point in time until his death in 1326, David received a steady stream of crown patronage. Apart from regaining the lordship of Chilham - and a grant of all Badlesmere's goods ${ }^{190}$ - David became a constable of the English army ${ }^{191}$ and chief warden of Northumberland and the adjoining Marches. ${ }^{192}$ Clearly, he was now a fixture in the English royal household.

For a man who had only returned to English allegiance in 1314, probably with very little money and uncertain prospects, Earl David III had vastly improved his 
personal and financial position by 1326 . During his life he changed allegiance four times: 1307, 1312, 1314 and 1321. On all four of these occasions, he was faced with what were undoubtedly difficult political and personal choices. On three of these dates, 1307,1312 and 1321 , he was presented with a sudden opportunity to regain possession of family lands and titles in either Scotland or England. In each of these instances the choice he made reaped dividends. In contrast, his actions during the battle of Bannockburn did not work in his favour and temporarily left Earl David without title to any of his ancestral lands in both countries. Of course, Earl David may simply have thought that Robert I had no chance of winning a major pitched battle against the English. However, a second factor, that of kin, clearly played a very important role in influencing earl David to adopt a particular political stance. It is obvious that whenever Earl David was faced with having to choose to oppose another Plantagenet, or their royal representative, in battle, he refused to do so. All this, it can be suggested, is not the behaviour of a 'traitor'. Abstract concepts like 'national loyalty' played no part in deciding Earl David's chosen course of action. Rather, his primary concern throughout his life was to preserve, or regain, different parts of his patrimony in Scotland and England in the face of varying pressures from competing royal dynasties.

\section{NOTES}

1 I would particularly like to thank David Ditchburn who, as supervisor of my MA dissertation, was closely involved in this project from its inception. Thanks are also due to Colm Ó Baoill, Sonja Cameron, Ulrike Morét and Grant G. Simpson for their helpful comments and suggestions on various aspects of this paper.

2 Norman H. Reid, 'Crown and Community under Robert I', in A. Grant and K. Stringer (eds), Medieval Scotland: Crown, Lordship and Community (Cambridge, 1993), 203-22 at 203-5.

3 G.W.S. Barrow, Robert Bruce and the Community of the Realm of Scotland (Edinburgh, 1988) [hereafter Barrow, Bruce], 262-311 at 275.

4 B. Webster, 'Scotland without a King, 1329-1341', in A. Grant and K. Stringer (eds), Medieval Scotland: Crown, Lordship and Community (Cambridge, 1993), 223-38 at 227.

5 A.A.M. Duncan, Scotland: The Making of the Kingdom (Edinburgh, 1975) [hereafter Duncan, Kingdom], 124-6 and at 533.

6 K.J. Stringer, Earl David of Huntingdon (Edinburgh, 1985), 207-11.

7 A.A.M. Duncan, 'The Earldom of Atholl in the Thirteenth Century', Scottish Genealogist, 8 (1960), 2-10 at 10 .

8 Earl John's parents, Isabella de Dover and Earl David II, were married by 1266 because Henry III waived $£ 100$ relief due by Earl David II and Isabella in December of that year for the lands which they hold as tenants in chief in England. These lands are not specified. However, unless the couple held other lands, of which there is no record in the primary sources, this extract must refer to Chilham and its associated manors. See: Calendar of the Close Rolls preserved in the Public Record Office (London, 1892-) [hereafter CCR], 1264-68, 272.

9 D.E.R. Watt, 'The Minority of Alexander III of Scotland', Transactions of the Royal Historical Society, 21 (1971), 1-23 at 9.

10 A. Young, Robert the Bruce's Rivals: The Comyns, 1212-1314 (East Linton, 1997) [hereafter Young, Comyns], 59. 
11 M. Prestwich, Edward I (2nd ed., London, 1997) [hereafter Prestwich, Edward], 26.

12 Keith Stringer and Alexander Grant, 'Scottish Foundations', in A. Grant and K.J. Stringer (eds), Uniting the Kingdom (London, 1995), 85-108 at 88.

13 Calendar of the Patent Rolls preserved in the Public Record Office (London, 1891-) [hereafter $C P R], 1266-72,110$ and 175.

14 See, for examplc, E.F. Jacob, Studies in the Period of Baronial Reform and Rebellion, 1258-1267 (Oxford, 1925), and F.M. Powicke, King Henry III and the Lord Edward, 2 vols. (Oxford, 1947).

15 D.E.R. Watt (general editor), Scotichronicon, 9 vols. (Aberdeen, 1987-) [hereafter Chron. Bower (Watt)], v, 349.

$16 \mathrm{~J}$. Bain (ed) and others, Calendar of Documents Relating to Scotland, 5 vols. (Edinburgh, 1881 1986) [hereafter $C D S$ ], ii, no. 1721. For information on the probable composition of the barony sec: $C P R, 1292-1301,432 ; C P R, 1266-72,422 ; C D S$, ii, no. 736 (p. 174) and $C P R, 1307-13,391$.

17 N.J.G. Pounds, The Medieval Castle in England and Wales (Cambridge, 1990), 148.

18 Chron. Bower (Watt), v, 375.

19 T. Rymer (ed), Foedera, Conventiones, Litterae e Cuiuscunque Generiis Acta Publica, 3 vols. (London, 1816-69) [hereafter Foedera], i, 644. The perception that the earldom of Atholl was in wardship for an extended period of time after 1270 is perhaps strengthened by an entry in the Melrose Chronicle [cf: Bannatyne Club, Chronica de Mailros (Edinburgh, 1835), 217] under the year-date 1269 which states, 'Obiit Lora comitissa Atholie, sepulta apud Melros'. This entry is placed after the obit of John I Comyn of Badenoch. According to most recent biographer of the Comyn family his death occurred c.1277 [cf: Young, Comyns, $\mathrm{x}$ ]. Therefore, the obit of Lora is either misplaced or wrongly dated. Of course, Isabella de Dover did not die until 1292 when she is still described as countess of Atholl [cf: William Stubbs (editor), The Historical Works of Gervase of Canterbury, 2 vols. (London 1879 and 1880), ii, 300] and the obit in the Melrose Chronicle cannot refer to her. However, the name of Alexander de Balliol's mother was Lora de Valoynes [cf: Joseph Bain, 'Sir Alexander Balliol of Cavers (Chamberlain of Scotland)', The Genealogist, new ser., iv (1887), 141-3]. Therefore, it might be asked whether the Melrose chronicler assumed that Lora de Valoynes was the countess of Atholl because her son had wardship of the earldom.

20 Foedera, 537.

21 Geoffrey Stell, 'The Balliol Family and the Great Cause of 1291-2', in K.J. Stringer (ed), Essays on the Nobility of Medieval Scotland (Edinburgh, 1985), 150-65 at 158.

22 Duncan, Kingdom, 178-9.

23 Young, Comyns, 72.

$24 C D S$, ii, no. 285.

25 A.A.M. Duncan (ed), Regesta Regum Scottorum v: The Acts of Robert I (Edinburgh, 1988) [hereafter RRS], no. 3 .

26 Young, Comyns, 52.

27 Chron. Bower (Watt), v, 373. If Bower's comment is correct, it would seem that there had been some tension between Earl David II de Strathbogie and John Comyn of Badenoch in 1269 over the building of a castle at Blair.

28 See, for example: $C D S$, ii, nos. 1440 and 1479.

29 In fact, the depth of kinship felt between the two branches of may have been extensive. As late as 6 November 1367, there is a record of king Edward III paying Elizabeth, countess of Atholl, $£ 100$ for the privilege of holding a Strathbogie infant at the holy font during christening [cf: Frederick Dean (ed), Issues of the Exchequer (London, 1837), 188].

30 Antonia Gransden, Historical Writing in England. Volume 2: c.1307 to the Early Sixteenth Century (London, 1982) [hereafter Gransden, Historical Writing], 24-5.

31 For accounts of the whole process of trial and execution see: Henry R. Luard (ed), Flores Historiarum, 3 vols. (London, 1890), iii, 134-5 and William Stubbs (ed), Chronicles of the Reigns of Edward I and Edward II: Annales Londoniensis and Annales Paulini, 2 vols., (London, 1882 and (883), i, 149.

$32 R R S, \mathrm{v}$, no. 373. 
33 J.M. Thomson and others (eds), Registrum Magni Sigilli Regum Scotorum (Edinburgh, 1882-1914) [hereafter RMS], i, App. 2, nos. 1004 and 1028. See also RRS, v, no. 99.

$34 R R S, \mathrm{v}$, no. 234.

35 B. Webster (ed), Regesta Regum Scottorum vi: The Acts of David II (Edinburgh, 1982), no. 504.

36 Calendar of Chancery Warrants 1244-1326 (London, 1927) [hereafter Cal. Chan. Warr.], 202.

37 Calendar of Fine Rolls (London, 1911-) [hereafter CFR], 1272-1307, 524-25.

$38 C D S$, ii, no. 1721 .

39 ibid., no. 591 . The financial breakdown of the manors in the Lordship of Chilham indicates that a total of 109 acres were sown with wheat, 105 acres with barley, 101 acres with oats and ninety-six acres with peas and vetches. In addition, the manors close to Chilham castle seem to have had an even spread of livestock consisting of cattle, pigs and sheep. This contrasts with the two manors of Ridelyngwolde and Kyngestone which show a much heavier concentration on pig farming. The total amount of livestock found on all of the manors attached to the Lordship were: six oxen, two cart-horses, fifty-nine cattle, 145 pigs and sixty-three sheep and lambs.

40 ibid., no. 736, (p. 174).

41 ibid., 173.

$42 C D S$, iv, no. 92.

43 A. Grant, Independence and Nationhood (London, 1984), 72-7.

44 Duncan, Kingdom, 426-7.

$45 C D S$, ii, no. 939.

46 Barrow, Bruce, 160.

$47 C D S$, iii, no. 1390.

$48 C D S$, ii, no. 940.

49 ibid., no. 942. The list is: Sir Laurence de Strathbolgy, Sir Henry de Inchmartin, Sir William de Moray, Sir Edmond de Ramsay, Sir John de Camburnon, Sir William de la Hay, Sir Walter de Berkeleye, knights, Simon de Hiskendy, John de Ireland, John de Strathbolgy, Robert de Mountour, William Bron, David de Cambernon, Gregor Makenerd, Walter Dalith, Thomas Dalith, Nicholas Dirlowenan, Malise de Logy, Walter de Buthergax, Robert de Inchethor, John Buterwan, Michael le Scot and Andrew de Strathgartney, vallets.

50 ibid., no. 1646, (p. 438).

51 Francis Palgrave, Documents and Records Illustrating the History of Scotland (London, 1837) [hereafter Palgrave, Documents], no. 76 (p. 314). Two other people given this designation also appear in the primary sources. These are David de Strathbolgy, esquire, (1296) [cf: $C C R, 1288-96$, 481-2] and Christinus de Strathbogie [cf: $C D S$, iii, 430].

52 D. MacPherson and others (eds), Rotuli Scotiae in Turri Londinensi et in Domo Capitulari Westmonasteriensi Asservati (London, 1814-19), i, 27a; Barrow, Bruce, 358, n. 89. The Cambron family also held the lands of Kinclaven, about ten miles east of Dunkeld, which may also have been within the boundaries of the earldom [cf: $C D S$, iii, 433].

53 Charles Rogers, Rental Book of the Cistercian Abbey of Cupar-Angus, 2 vols. (London, 1879), i, 332.

54 Earl David II de Strathbogie and members of the Cambron family also witnessed Inchmartin charters of donation to Cupar abbey [cf: $C D S$, ii, 349-50].

55 ibid., no. 733.

56 National Archives of Scotland [NAS], GD50/130/1 (insert). Other witnesses to this charter are: John de Inchmartyn, John de Cambron, Archibald de Livingstone, Lawrence de Strathbolgy, William Olifard and Henry de Inchmartyn.

57 E.L.G. Stones and Grant G. Simpson, Edward I and the Throne of Scotland 1290-1296, 2 vols. (Oxford, 1978) [hereafter Stones and Simpson, Edward], ii, 369-70.

58 Grant G. Simpson (ed), Handlist of Acts of Alexander III (Edinburgh, 1960), no. 80, records Broun family lands in Coalston, east Lothian.

59 F.J. Amours (ed), The Original Chronicle of Andrew of Wyntoun (Scottish Texts Society, 1908), vi, $68,1.4500$. 
$60 C D S$, iii, no. 731.

$61 C D S$, ii, p. 198.

62 Cynthia J. Neville, 'The Earls of Stratheam from the Twelfth to the Mid-Fourteenth Century, with an edition of their written acts', 2 vols. (University of Aberdeen, unpublished PhD Thesis, 1983), i, 176-7.

63 ibid., 121.

64 ibid., 176.

65 For example: $C D S$, ii, no. 742.

$66 C C R, 1288-96,481$.

$67 C D S$, iii, nos. 839 and $959 ; C D S$, v, nos. 492 and 562 .

$68 C D S$, iii, no. 1231.

69 G.W.S. Barrow, The Anglo-Norman Era in Scottish History (Oxford, 1980), 182.

70 RMS, i, App 2, no. 1396.

71 S. Boardman, The Early Stewart Kings: Robert II and Robert III (East Linton, 1996), 169.

72 Stones and Simpson, Edward, if, 82.

Barrow, Bruce, 156.

74 Stones and Simpson, Edward, ii, 220-1.

75 Barrow, Bruce, 65.

Foedera, i, 804.

77 J. Stevenson (ed), Chronicon de Lanercost (Maitland Club, 1839), 176.

78 CDS, ii, no. 742.

79 ibid., no. 1978. John is not actually named in this damaged document but Barrow has convincingly argued that his name was originally on the document. See: Barrow, Bruce, 347, n. 99.

80 Fiona Watson, Under the Hammer (East Linton, 1998) [hereafter Watson, Hammer], 116.

81 Alexander is witnessing documents for John I Balliol in 1293, swore fealty to Edward I in 1296 and seems to have remained loyal to Edward I thereafter. See: $C D S$, ii, nos. 660,768 and 961 .

82 ibid., no. 1440.

83 Palgrave, Documents, 278-82.

84 Watson, Hammer, 145-6.

85 Prestwich, Edward, 500-2.

$86 C D S$, ii, no. 961.

87 ibid., no. 1978.

88 Cal. Chan. Warr., 205.

$89 C D S$, ii, no. 1592.

$90 C P R, 1292-1301,336$

91 Barrow, Bruce, 122-3.

$92 C D S$, ii, no. 1633. For the history behind this letter, see, Barrow, Bruce, 107.

93 CFR, i, 524-5.

$94 C P R, 1292-1301,377$. Simon Ganet was appointed to be his attorney for this period to look after the earl's affairs in England.

95 See, E.L.G. Stones (ed), Anglo-Scottish Relations 1174-1328 (Edinburgh, 1965), 120-9 at 120, where Stones translates 'terre' as 'realm'.

96 ibid., 130-4.

97 Barrow, Bruce, 148.

98 ibid., 161.

99 CCR, 1288-1296, 125-7.

$100 C D S$, iii, no. 513 .

$101 R R S$, v, no. 372.

$102 C D S$, iii, no. 512.

$103 C D S$, ii, no. 1826.

104 ibid., no. 1979.

105 Matthew P. MacDiarmid and James A.C. Stevenson (eds), Barbour's Bruce (Scottish Texts 
Society, 1980-85) [hereafter MacDiarmid and Stevenson, Bruce], ii, 220.

106 ibid., i, 83.

107 Patricia M. Barnes and G.W.S. Barrow, 'The Movements of Robert Bruce between September 1307 and May 1308', Scottish Historical Review, 49 (1970), 46-59, at 58.

108 A.A.M. Duncan, The Bruce (Edinburgh, 1997) [hereafter Duncan, Bruce], 332.

109 MacDiarmid and Stevenson, Bruce, i, 83.

110 Sonja Väthjunker, 'A Study of the Career of Sir James Douglas-The Historical Record Versus Barbour's Bruce' (University of Aberdeen, unpublished PhD Thesis, 1992) [hereafter Väthjunker, Douglas], 37-40.

111 J.R.S. Phillips, Aymer de Valence (Oxford, 1972) [hereafter Phillips, Valence], 3.

$112 C P R, 1301-1307,534$.

$113 C D S$, iii, no. 5 .

114 ibid., no. 200.

$115 C P R, 1307-1313$, no. 108 and at p. 404.

$116 C F R, \mathrm{ii}, 170$.

$117 C D S$, iii, no. 240.

$118 C P R, 1301-1307,432$.

$119 C P R, 1307-1313,3$.

120 ibid., 391.

$121 R R S, \mathrm{v}$, no. 41. This is made clear by a later document of 1323 [cf: RRS, v, no. 234] which expressly states when Earl David III de Strathbogie was disinherited.

122 ibid., 64.

123 RRS, vi, no. 178

124 Barrow, Bruce, 275.

$125 R M S$, i, App. 2, nos. 1004 and 1028.

126 ibid., App. 2, nos. 441, 622, 623 and 624 .

127 Young, Comyns, 206-7.

128 J. Stuart and others (eds), The Exchequer Rolls of Scotland, 23 vols. (Edinburgh, 1878-1908), i, 52.

129 NAS, GD50/130/3.

130 G.W.S. Bartow, The Kingdom of the Scots (London, 1973), 374-5.

131 RRS, v, nos. 372 and 373.

132 ibid., 64.

$133 C D S$, iii, no. 512.

134 Young, Comyns, xii

$135 C C R, 1313-18,130$.

136 ibid., 138.

137 CPR, 1313-17, 198.

$138 C D S$, iii, no. 396.

139 CCR, 1323-27, 447-8.

$140 C D S$, iii, no. 506. Earl David III's brother John was also included [cf: ibid., no. 513]

141 ibid., no. 520.

142 ibid., no. 424. It might be suggested, in view of Badlesmere's position as royal councillor, that Earl David III was quoting the ordinance about 'evil councillors'.

143 J.R. Maddicott, Thomas of Lancaster 1307-1322 (Oxford, 1970) [hereafter Maddicott, Lancaster], 164-5.

144 G.A. Holmes, The Estates of the Higher Nobility in Fourteenth-Century England (Cambridge, 1957) [hereafter Holmes, Estates], 141.

$145 C P R, 1321-24,33$.

146 Calendar of Memoranda Rolls (Exchequer) 1326-27 (London, 1968), no. 240.

147 CFR, iii, 298.

148 The financial records pertaining to the Norfolk manors which Earl David III inherited from Aymer de Valence have been published [cf: William Hassall and Jacques Beauray (eds), Lordship and 
Landscape in Norfolk 1250-1350 (Oxford, 1993)] although they do not contain very much information relating to the Strathbogic fanily.

$149 C D S$, iii, nos. 864 and 900.

150 RRS, v, no. 24.

151 ibid., no. 28 .

152 Barrow, Bruce, 237.

153 A.A.M. Duncan, 'The War of the Scots, 1306-23', Transactions of the Royal Historical Society, 6th ser., 2 (1992), 125-51 at 149 .

$154 R R S, v$, no. 234. There were only two parliaments held at Cambuskenneth during the reign of Robert I, 1314 and 1326 and sec Duncan's notes on this letter for the substitution of Hastings with Strathbogic.

155 W.F. Skene (cd), John of Fordun's Chronicle of the Scottish Nation, 2 vols. (Llanerch, reprint 1993), ii, 338; MacDiarmid and Stevenson, Bruce, ii, 222-6 and Chron. Bower (Watt), vi, 347.

156 J. Stevenson (ed), Scalacronica, by Sir Thomas Grey of Heton knight. A Chronicle of England and Scotland from AD MLXXI to AD MCCCLXII (Maitland Club, 1836), 140-1.

157 Barrow, Bruce, 194, makes no mention of the role played by earl David III in his main description of the attack on Perth although he devotes a small sentence at a later point in his narrative, based on Gray's testimony, and states that the earl played a notable part in the action [cf: ibid., 275].

158 Duncan, Bruce, 337-8.

159 Gransden, Historical Writing, ii, 92-5.

160 For example: Vathjunker, Douglas, 256-60.

161 MacDiarmid and Stevenson, Bruce, iii, 68-9. The ordinances for the good government of Scotland (1305) [cf: Stones, Relations, 123] name William of Airth as sheriff of Forfar. The Strathbogie family held lands in this area of Scotland.

162 Duncan, Bruce, '504-5n.'.

163 Barrow, Bruce, 277.

164 Sonja Cameron, 'Chivalry and Warfare in Barbour's Bruce', in Matthew Strickland (ed), Armies, Chivalry and Warfare in Medieval Britain and France (Stamford, 1998), 13-29 at 13-4.

165 Sec: M. Prestwich, Armies and Warfare in the Middle Ages (London, 1996), 171-5 for the different roles of constable and marshal in the English army. If their roles were the same in the Scottish army, Duncan's suggestion [cf: Duncan, Bruce, 506] that Earl David III was at Cambuskenneth because one of the constables' functions was to look after horse fodder is wrong. This would have been the responsibility of the marshal.

166 Sonja Cameron, 'Keeping the Customer Satisfied: Barbour's Bruce and a Phantom Division at Bannockburn', in E.J. Cowan (ed), The Polar Twins (Edinburgh, 1999), (forthcoming).

167 S. Cameron and A. Ross, 'The Treaty of Edinburgh and the Disinherited (1328-1332)', in History, 84 (1999), 237-56.

$168 C P R, 1321-24,349$.

169 The Lornyn family were disinherited by king David II by 1343, possibly because Sir Eustace de Lornyn had handed Roxburgh castle over to the English [cf: $C D S$, iii, no. 1410; $R M S, \mathrm{i}, 62$, no.197].

$170 R R S, \mathrm{v}$, no. 234

171 Barrow, Bruce, 299.

$172 R R S, v$, no. 394 shows that John Campbell entered into a private agreement with Dunfermline abbey for the lands of Moulin after the lawsuit was settled in the abbey's favour. He is not described as earl of Atholl which may indicate that he was still a minor.

173 Foedera, ii, 437; CDS, iii, nos. 842 and 860.

174 Hector MacQueen, Common Law and Feudal Society in Medieval Scotland (Edinburgh, 1993), 169-78.

$175 R R S$, v, no. 41.

176 A new evaluation of the plot has recently been completed: Michael Penman, 'A fell coniuracioun agayn Robert the douchty king: the Soules conspiracy of 1318-1320, Innes Review, 50 (1999), 25- 
57.

$177 C D S$, iii, no. 729.

178 ibid., no. 731.

179 Francis Palgrave, Parliamentary Writs, 4 vols. (London, 1827-34) [hereafter Palgrave, Writs], iv, 1322.

180 Maddicott, Lancaster, 56

181 Holmes, Estates, 141.

182 Phillips, Valence, 30-7.

$183 C P R, 1317-21,227$.

$184 C D S$, iii, no. 709.

185 Maddicott, Lancaster, 56.

186 Phillips, Valence, 197-200.

187 Palgrave, Writs, iv, 1467.

$188 C P R, 1321-24,33$.

189 Phillips, Valence, 215-7.

$190 C P R, 1321-24,206$.

$191 C D S$, iii, no. 748.

192 CPR, 1321-24, 205.

\section{Appendix 1}

John I, King of England

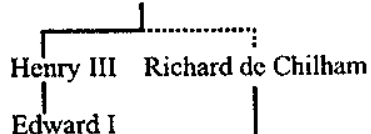

Edward I
1

Isabclla de Ch

\section{STRATHBOGIE GENEALOGY}

Earls of Fifc

$$
1
$$

David de Strathbogic, Lord of Strathbogic

$$
\text { fi: } 1226
$$

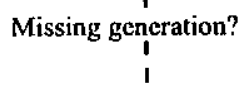

Ist Strathbogie Earl of Atholl

$$
\text { d. } 1270
$$

illegitimate line of descent

possible line of descent
Earl John, m. Isabella of Mar exec. 1306

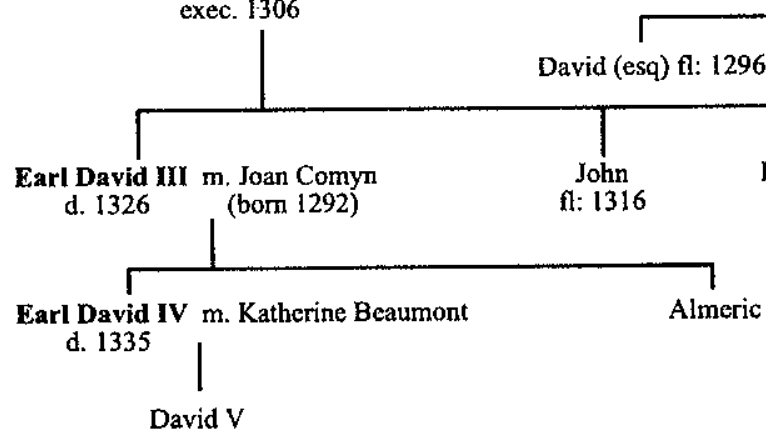

Sir Laurenice fl: 1296

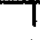

hn (esq) fl: 1296

Christinus fl: 1315
Edward Bruce (1) Isabclla (2) John Campbell (3) d. 1318

fl: 1329

d. 1333

Alexander Bruce

d. 1333, Earl of Carrick 


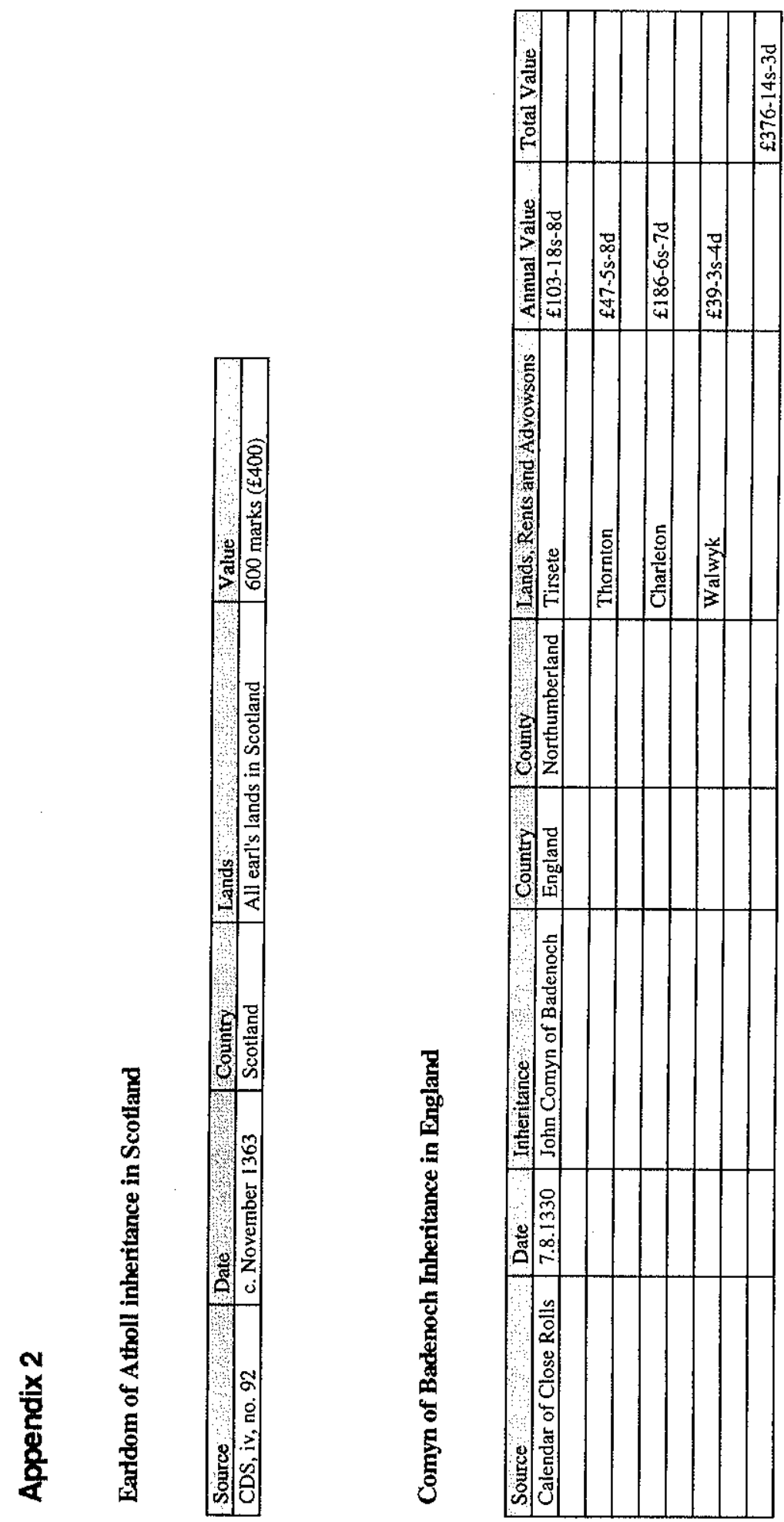




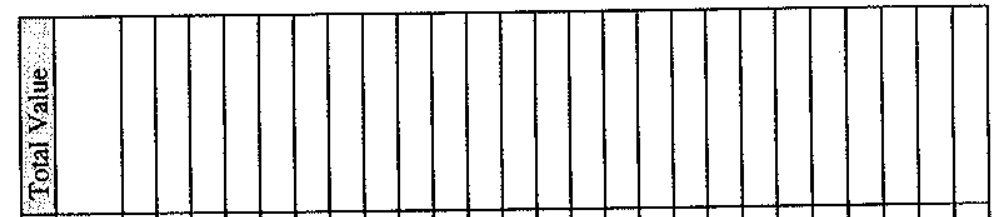

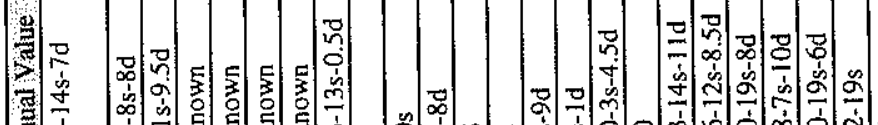

重鹪
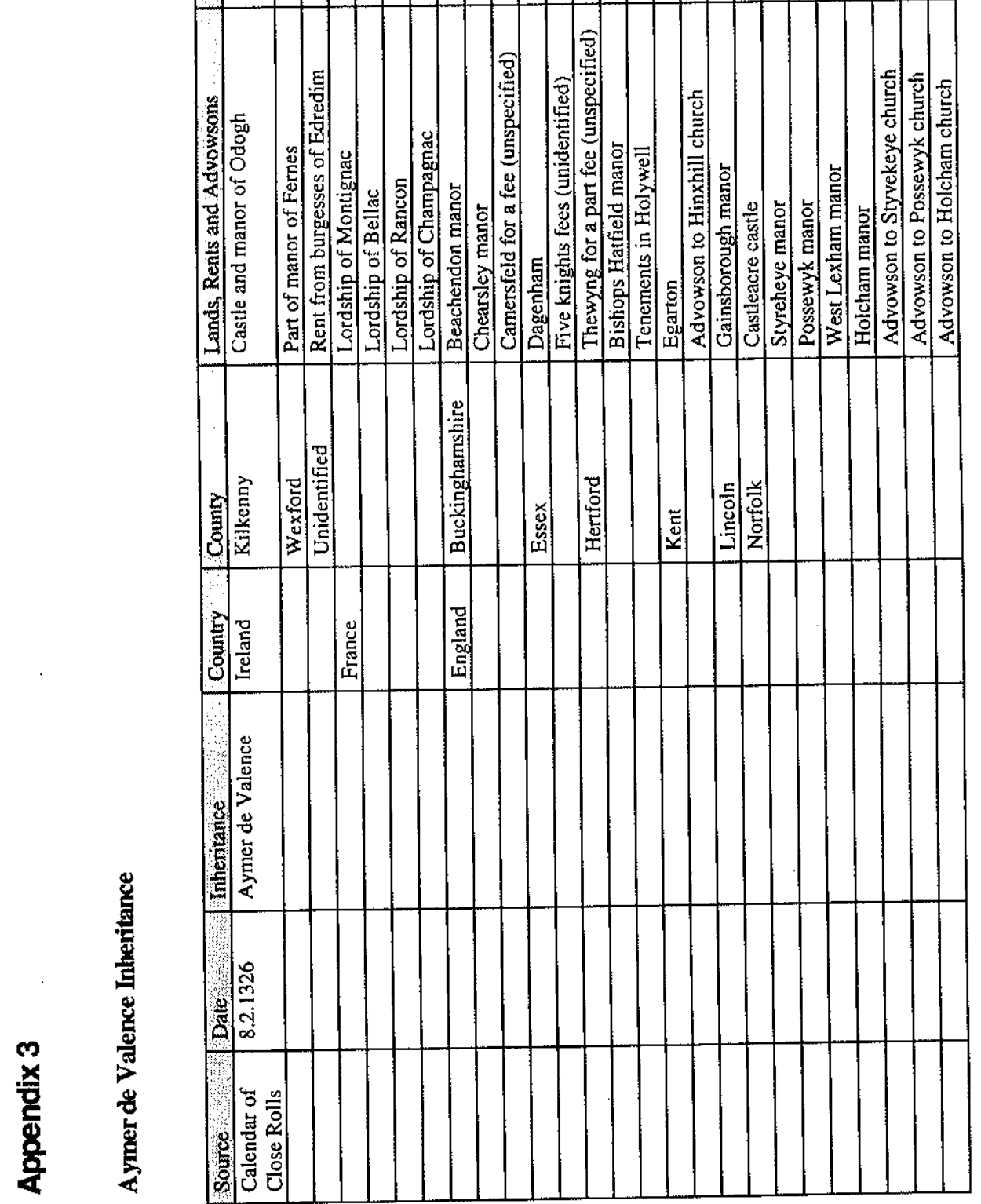
THE STRATHBOGIE EARLS OF ATHOLL

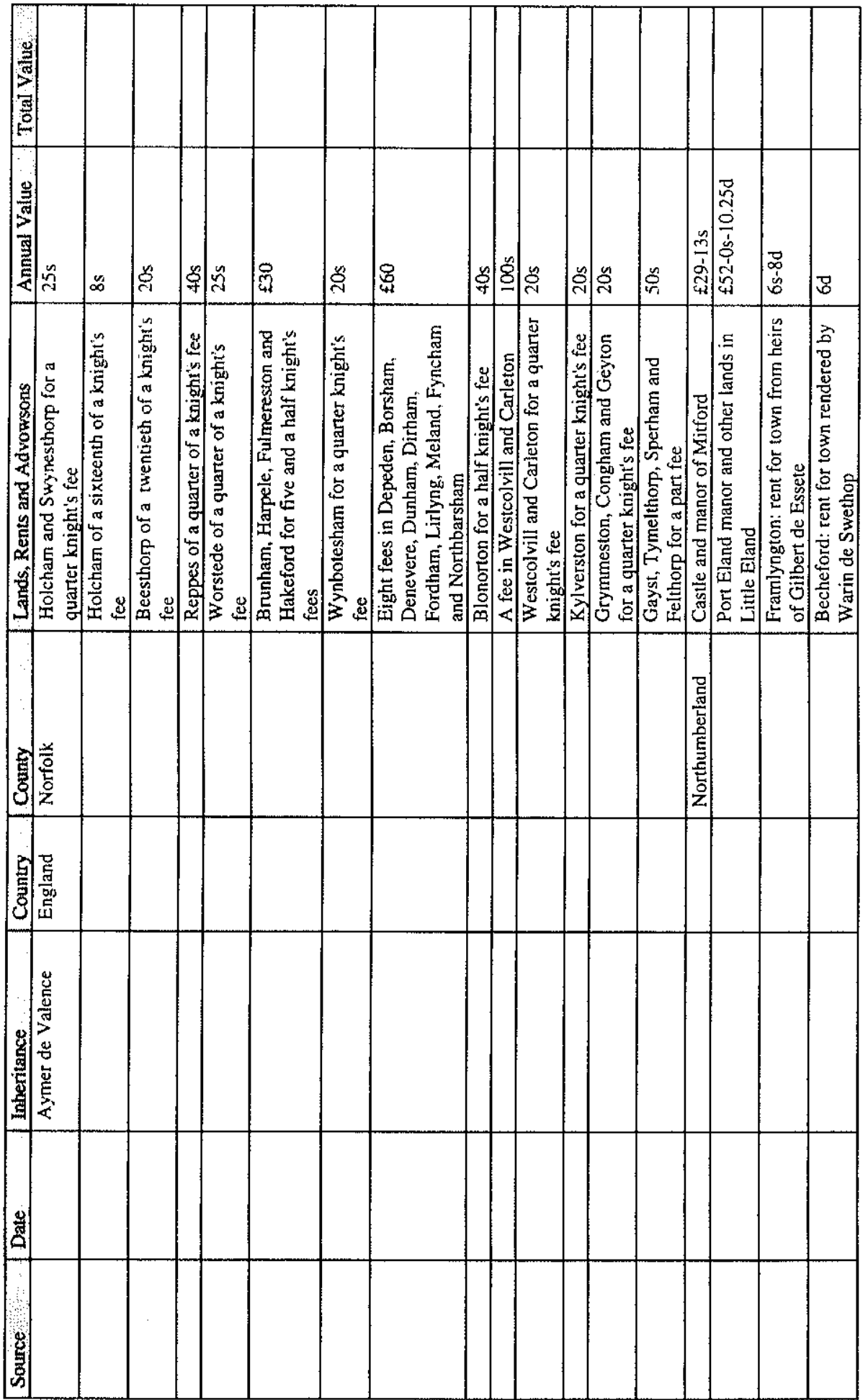




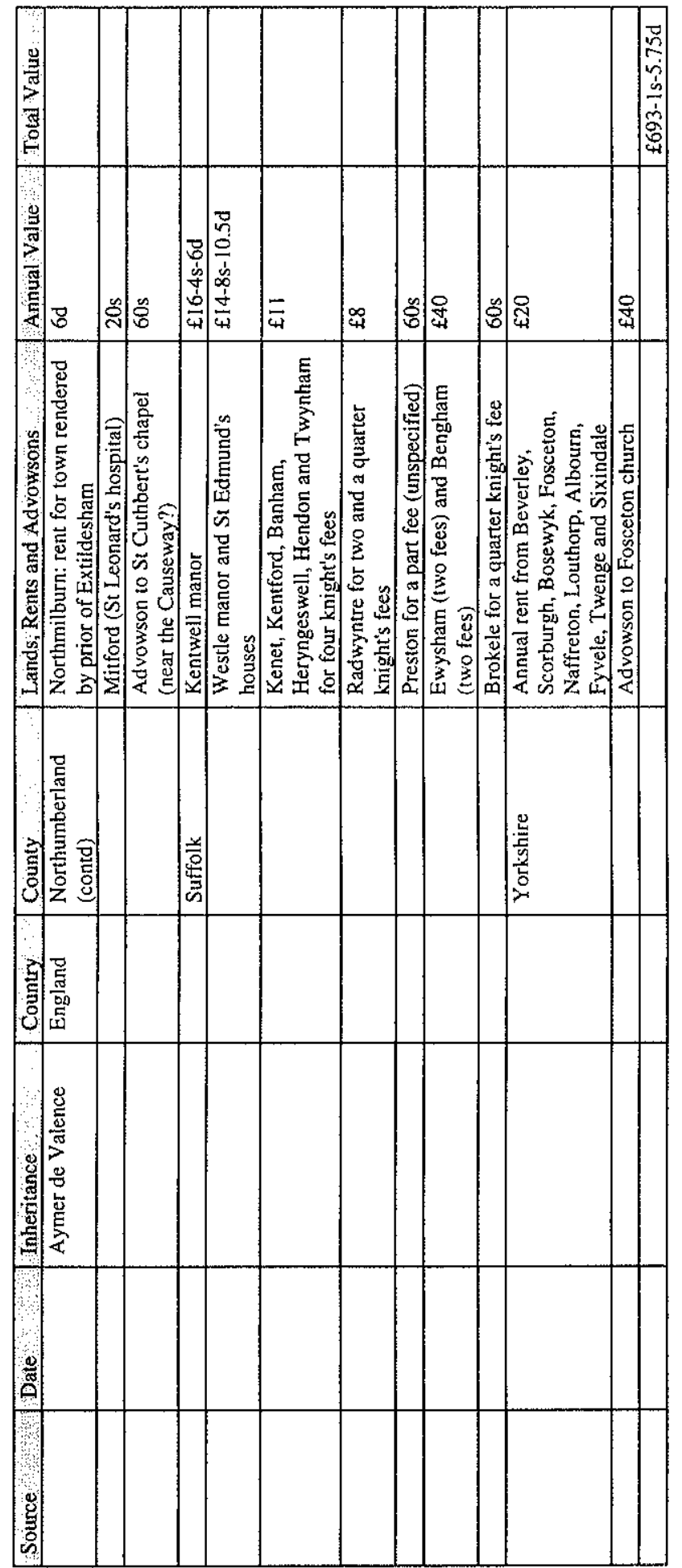

